\title{
O DESENHO DA FIGURA PELA PERSPECTIVA PIAGETIANA
}

\section{ARTIGO DE REVISÃO}

ABREU, Liliane Alcântara de ${ }^{1}$, NUNES, Letícia Monteiro ${ }^{2}$, SOARES, Pamela Cristina ${ }^{3}$, REHDER, Giovanna de Souza ${ }^{4}$, MELO, Natalia Sayuri ${ }^{5}$, SILVA, Gabriella Braga Dias da ${ }^{6}$, MENDES, Matheus Passos ${ }^{7}$

ABREU, Liliane Alcântara de. Et al. O desenho da figura pela perspectiva piagetiana. Revista Científica Multidisciplinar Núcleo do Conhecimento. Ano. 07, Ed. 01, Vol. 05, pp. 60-93. Janeiro de 2022. ISSN: 2448-0959, Link de acesso: https://www.nucleodoconhecimento.com.br/psicologia/perspectivapiagetiana

1 Especialista em Neurociência Pedagógica pela AVM Educacional/UCAM/RJ; especialista em Arteterapia em Educação e Saúde pela AVM Educacional/UCAM/RJ; especialista em Pesquisa de Comportamento e Consumo pela Faculdade SENAI CETIQT RJ; especialista em Artes Visuais pela UNESA/RJ; bacharela em Design pela Faculdade SENAI CETIQT RJ. Bacharelanda em Psicologia pela UNIP/SP.

${ }^{2}$ Bacharelanda em Psicologia pela UNIP/SP.

${ }^{3}$ Bacharelanda em Psicologia pela UNIP/SP.

${ }^{4}$ Bacharelanda em Psicologia pela UNIP/SP.

${ }^{5}$ Bacharela em Comunicação Social pela Faculdade Casper Libero/SP. Bacharelanda em Psicologia pela UNIP/SP.

${ }^{6}$ Bacharelanda em Psicologia pela UNIP/SP.

${ }^{7}$ Bacharelando em Psicologia pela UNIP/SP.

RC: 105382

Disponível em: https://www.nucleodoconhecimento.com.br/psicologia/perspectiva-piagetiana 


\section{RESUMO}

O presente artigo é resultado de uma análise de desenhos livres de indivíduos dentro das fases de desenvolvimento narradas por Piaget (1994; 1999), considerando não somente seus estudos sob a perspectiva dos estádios da criança, mas também como funcionaria a evolução de um sujeito através de desenhos e analisados pelo prisma psicológico, com base principal em Georges-Henri Luquet (1969). O problema norteador da pesquisa: é possível detectar diferenças no desenvolvimento psíquico de crianças e apontar fatores comportamentais e emocionais através de desenhos? Assim, o objetivo geral concentra-se em identificar e avaliar as fases de desenvolvimento da criança por meio de desenhos. A metodologia da pesquisa incluiu a revisão bibliográfica, com uma abordagem em quatro crianças com idade entre 2 a 15 anos, de ambos os gêneros, e sem classe social determinante na cidade de São Paulo. Além disso, a premissa de hipótese foi de que as diferenças de fases de desenvolvimento poderiam ser de fácil identificação a partir do conhecimento das teorizações de Piaget, Luquet, Lowenfeld, Brittain, e Florence de Meredieu. Ademais, seria possível que materiais gráficos pudessem influenciar na transferência emocional aos desenhos, e colaborar na leitura avaliativa. Como resultados e conclusões, percebeu-se que é cabível identificar as diferentes fases de desenvolvimento da criança através de desenhos, e que até os materiais utilizados colaboram no reconhecimento das estruturas psicológicas dos indivíduos. Além disso, reforçou-se a importância dessa atividade lúdica como um dos métodos usados pela Psicologia para compreender melhor a personalidade e as possíveis angústias de uma pessoa pelo grafismo, independentemente de sua idade.

Palavras-chave: Cognição, Construtivismo, Desenho, Desenvolvimento, Psicologia.

RC: 105382

Disponível em: https://www.nucleodoconhecimento.com.br/psicologia/perspectiva-piagetiana 


\section{INTRODUÇÃO}

Este artigo teve a finalidade de analisar desenhos livres de indivíduos dentro das fases de desenvolvimento descritas por Piaget $(1994 ; 1999)$. Para tanto, foi levado em consideração não só seus estudos sob a perspectiva do primeiro estádio da criança, mas como funcionaria a evolução de um sujeito através de desenhos e analisados pelo prisma psicológico com base principal em Georges-Henri Luquet (1969).

Buscando as reais interseções entre esses fatores, surgiu a dúvida que deu origem ao problema norteador: é possível se detectar diferenças no desenvolvimento psíquico de crianças e apontar fatores comportamentais e emocionais por meio de desenhos? Assim, o objetivo geral se concentrou em identificar e avaliar as fases de desenvolvimento da criança por meio de desenhos. Como consequência, os objetivos específicos se ampliaram em detectar se as antigas teorizações piagetianas ainda podem ser validadas nos indivíduos contemporâneos; compreender se materiais utilizados na elaboração dos desenhos podem corroborar com a leitura psicológica, e entender como fazer as devidas leituras de fases etárias e dos conteúdos de desenhos comparando com a teoria de Piaget.

Já a metodologia da pesquisa foi composta por revisão bibliográfica e coma abordagem em um grupo de quatro crianças voluntárias com idade entre 2 a 15 anos, de ambos os gêneros, e sem classe social determinante na cidade de São Paulo, no primeiro semestre (fevereiro a maio) de 2019. Sendo assim, fez-se necessário entender brevemente cada um desses pontos como ferramenta para compreensão dos processos que compõem o processo cognitivo e evolutivo do ser humano.

Na seção 2, foram utilizadas as proposições de Piaget $(1994 ; 1999)$ para discorrer sobre as fases de desenvolvimento de crianças e adolescentes. A seção 3 se subdivide em três partes, sendo a primeira abordando o desenvolvimento psíquico através do desenho, e tendo como fundamentação teórica Florence de Meredieu

RC: 105382

Disponível em: https://www.nucleodoconhecimento.com.br/psicologia/perspectiva-piagetiana 
(2000), e Stephen Farting (2011). Já a segunda parte discute como os desenhos funcionam no processo de maturidade do indivíduo, e traz a teorização de GeorgesHenri Luquet (1969), com o apoio de Viktor Lowenfeld e W. Lambert Brittain (1977), e novamente Meredieu. Outros autores como Sigmund Freud (1972), Melaine Klein (1991-1997, John Buck (2003), Maria Ocampo, et al. (2005) e Maria Retondo (2000), são brevemente citados. Na terceira subdivisão, Eveline Carrano e Maria Requião (2013) dão o suporte sobre a influência de materiais gráficos e artísticos no psiquismo do indivíduo, e, dessa forma, pode-se relacionar com todas as informações anteriores e da pesquisa feita com os voluntários. A seção 4 apresenta os dados coletados e seus resultados, através da abordagem com as quatro crianças pesquisadas. Por fim, as considerações finais encerram este artigo.

\section{O DESENVOLVIMENTO MENTAL DA CRIANÇA SEGUNDO PIAGET}

De acordo com Piaget (1994; 1999), o desenvolvimento psíquico ocorre durante toda a vida, começando na infância e terminando na fase adulta. Alguns indivíduos apresentam uma falha nesse processo, sobretudo na infância, o que explica as ocorrências comuns como comportamentos infantis em adultos.

Se de um lado existem funções imutáveis e comuns, de outro existem as estruturas variáveis. Essas são as formas de organização da atividade mental, tanto do aspecto motor ou intelectual, quanto afetivo (individual e social). É aí que surgem as seis estruturas originais e sucessivas reconhecidas por Piaget (1994; 1999), sendo que cada uma configura uma construção diferente da anterior: recém-nascido e lactente (que já engloba três estruturas), primeira infância, infância e adolescência.

As necessidades se caracterizam basicamente por demarcar certos aspectos do mundo às estruturas que o indivíduo decodificou, assim como, reajustar o entendimento daquilo que se transformava nesse processo. Em outras palavras, é um processo de assimilação progressiva de novas informações geradas pelo meio

RC: 105382

Disponível em: https://www.nucleodoconhecimento.com.br/psicologia/perspectiva-piagetiana 
ambiente, e, acomodação dessas referências para configurar o real entendimento e aprendizado. Tudo faz parte do processo de adaptação que configura o equilíbrio psíquico.

As três primeiras estruturas de estágios (ou estádios) são referentes ao recémnascido e lactente, e que vai do nascimento aos dois anos. O estágio dos reflexos ou mecanismos hereditários fazem parte da primeira fase de adaptação, e encontra-se no indivíduo recém-nascido ou lactente, ou seja, do nascimento até por volta dos dezoito meses ou dois anos. Durante esse período, o sujeito assim que nasce, passa pela fase do reflexo (correspondente às tendências instintivas), em que suas funções são voltadas apenas para a nutrição. Esses reflexos voltados para a sucção, evoluem com o passar dos dias. Aspectos egocêntricos também já podem ser observados nesse estágio, pois o sujeito não tem a capacidade de diferenciar o eu da realidade exterior.

O estágio dos primeiros hábitos motores, percepções organizadas e sentimentos diferenciados integra-se na segunda etapa (mais ou menos no segundo mês de vida) em que o bebê passa a identificar as expressões faciais e suga o polegar. Entre três e seis meses, ele começa a pegar objetos e isso desencadeia os esquemas sensóriomotores, que são os conjuntos de novos hábitos motores e perceptivos. Esse segundo estágio identificado como de percepções e hábitos, corresponde aos sentimentos elementares, como agradável e desagradável, prazer e dor, conforme Piaget (1999). É nesse estágio que ocorrem os primeiros sinais de interesse por seu próprio corpo, como mãos e pés, mas sem consciência pessoal ou do que realmente são aquelas coisas.

O terceiro estágio é o de inteligência sensório-motora ou prática (anterior à linguagem), das regulações afetivas e fixações exteriores de afetividade. Essa fase ocorre por volta dos dezoito meses, sendo ainda anterior ao desenvolvimento da

RC: 105382

Disponível em: https://www.nucleodoconhecimento.com.br/psicologia/perspectiva-piagetiana 
linguagem e pensamento. Ela se refere ao manuseio de objetos, de como usar uma vareta para alcançar um brinquedo.

Nessa etapa, o bebê associa objetos à esquemas de ação, agitando ou esfregandoos para compreendê-los através do uso, transformando dessa forma a representação das coisas. O egocentrismo primitivo se projeta, pois, a criança acha que tudo ocorre por causa dela e por ela. Ao fim do segundo ano, o autor explica que essa visão modifica, e, assim, o indivíduo passa a entender melhor as relações de causas sobre objetos e campo. Ademais, o indivíduo nesse período inicial de dois anos apresenta quatro processos fundamentais nessa evolução intelectual. Piaget $(1999$, p. 21) diz que são as construções de categoria de objeto e do espaço, da causalidade e do tempo. Isso desencadeia a questão perceptiva (no final do segundo ano), e justamente porque a criança consegue ter uma totalidade de espaço, inclusive do próprio corpo, devido a coordenação de movimentos que ampliam o desenvolvimento da inteligência senso-motora. Portanto, suas funções motoras e cognitivas evoluem sensivelmente conforme mais estimuladas no setor afetivo e intelectual, aspectos esses que não podem ser dissociados no desenvolvimento humano.

O quarto estágio é o de inteligência intuitiva, sentimentos interindividuais espontâneos e relações sociais de submissão ao adulto, que ocorre dos dois aos sete anos. Essa quarta estrutura identificada pelo autor é o estágio da primeira infância, que acontece

dos dois aos sete anos. É o período de surgimento da linguagem e que o indivíduo consegue não só falar sobre si, mas relatar pequenos eventos passados, construir narrativas, antecipar ações futuras e perguntar... perguntar muito a respeito de tudo. Assim, o autor discorre que o sujeito desenvolve e modifica nesse estágio, condutas ligadas à socialização, pensamento e intuição. Para tanto, ele divide em quatro esses pilares principais (socialização, pensamento, intuição e afeto):

RC: 105382

Disponível em: https://www.nucleodoconhecimento.com.br/psicologia/perspectiva-piagetiana 
a) Socialização da ação: demarcada essencialmente pelo desenvolvimento da linguagem, tem sua iniciação desde o primeiro estágio (no nascimento) com o aprendizado do lactente sob o aspecto da imitação.

b) Gênese do pensamento: é efetivamente a mudança e transformação da inteligência senso-motora para a linguagem de socialização. Ali é que o sujeito vai contar suas ações, reconstituir o passado e formular o futuro. A palavra pode ser formulada sem a presença do objeto. $O$ pensamento pode ser apresentado de forma concreta.

Os jogos são simbólicos (de imaginação e imitação), como brincar de boneca ou de comidinha. Segundo Piaget (1999), esse tipo de jogo configura o pensamento real, mas duplamente egocêntrico. Isso porque consiste em satisfazer o eu por meio de uma transformação. $O$ autor explica que ao brincar de boneca, a criança revive, refaz e corrige sua própria vida, completando com ficção sua realidade. Portanto, uma assimilação deformada do eu real. Outro senão, é que ao usar simbolismos (signos), e, portanto, imagens, novamente estados íntimos vêm à tona, e assim, o pensamento retoma a estrutura de duplo sentido.

Outro extremo é o pensamento verbal, mais distante do real do que da intuição. Nessa etapa, sobretudo a partir dos três anos, o teórico traz a referência sobre a fase dos porquês. A criança vai perguntar dezenas de vezes um aspecto até que as dúvidas se extingam. Os sujeitos buscam razões causais e finalísticas sobre fenômenos gerais. Para o autor, esse momento específico configura a continuidade do pensamento egocêntrico da criança, pois haveria um prolongamento dos esquemas práticos.

Outra característica marcante é o animismo dos objetos. O autor explica que primeiro isso ocorre em objetos que falam por si (a lâmpada que acende). Depois, agentes e corpos (como nuvens e astros). Ele cita: "Mais tarde, só o movimento espontâneo será dotado de consciência. Por exemplo, as nuvens não sabem mais 'porque o vento as

RC: 105382

Disponível em: https://www.nucleodoconhecimento.com.br/psicologia/perspectiva-piagetiana 
empurras'; mas o vento não sabe as coisas 'porque é uma pessoa' como nós, mas 'sabe que sopra, porque é ele quem sopra'." (PIAGET, 1999, p. 31)

Piaget (1999, p. 32) é categórico que toda a casualidade na primeira infância é resultante da "indiferenciação entre o psíquico e o físico e o egocentrismo intelectual".

c) Intuição: apesar de influenciados pelo finalismo e com dificuldade de justificativa quando inquiridos, crianças na primeira infância desconfiam das pessoas que nunca apresentam provas sobre o que falam. Conforme o autor, a intuição primária caracteriza-se por uma ação global, enquanto a intuição articulada ultrapassa as consequências dessa ação e de uma reconstituição.

d) Vida afetiva: a socialização está ligada intrinsecamente ao processo de desenvolvimento afetivo e funções intelectuais, lembrando ainda que ambos não são dissociados. Valores morais como fatores normativos são igualmente construídos nessa etapa, como por exemplo, o valor da mentira e da verdade.

Então, chega-se à quinta estrutura identificada por Piaget (1999), que é a infância, e advém dos sete aos onze anos. O quinto estágio se refere às operações intelectuais concretas (a lógica) e sentimentos morais e sociais de cooperação, indo dos sete aos onze anos. Essa fase coincide com o momento em que a criança ingressa no universo da escolaridade e acontece uma modificação no desenvolvimento mental. O estudioso descreve que as novas relações sociais são imprescindíveis para a formatação e construção ininterrupta das interações cognitivas e de sociabilização. Assim, novamente o autor divide essa fase em quatro pilares principais para um melhor detalhamento (socialização, pensamento, racionalização e afeto). Note que agora tem-se a racionalização, na fase anterior ela era regida pela intuição.

a) Progressos de conduta e de socialização: Por estarem em grande exposição de grupo, as crianças tornam-se mais solidárias, reforçando ou desenvolvendo a capacidade de cooperação. Segundo o teórico, separam seus pontos de vista do RC: 105382

Disponível em: https://www.nucleodoconhecimento.com.br/psicologia/perspectiva-piagetiana 
outro, e desenvolvem a argumentação e defesa. Essa nova percepção de mundo precipita o fim total do egocentrismo que produzia atitudes impulsivas e que acompanhou o indivíduo desde seu nascimento. Sem o egocentrismo, o sujeito passa a pensar antes de agir, iniciando o processo de reflexão e acelerando a socialização. A coletividade reforça o seguimento de regras sociais através dos jogos e brincadeiras em grupo, e até mesmo pela condução de aceitação no espaço escolar para aceitação e convivência naquele grupo diferente do habitual da casa.

No caso dos jogos, o autor explica que se a tendência de crianças entre quatro e seis anos é a de imitar os mais velhos para criar ou participar das brincadeiras, e em uma conduta que desconhece todas as regras e sem coordenação. A partir do momento que esse indivíduo chega na infância (sete anos), ele compreende as regras e as segue, criando também o entendimento de igualdade diante de leis. Da mesma forma, a compatibilidade se estabelece. Portanto, a construção lógica sobre as relações sociais e diferenças se intensifica ressignificando um novo sistema de valores e fortalecendo o campo afetivo. Cognição e emoção se expandem sob os determinantes de lógica e moral.

b) Progressos de pensamento: Segundo o teórico, na mudança de etapa da primeira infância para a infância, e com a extinção do egocentrismo, o sujeito transmuta essa percepção do mundo por mim para eu e o mundo. Ele passa a se identificar como parte de algo. O animismo, finalismo e artificialismo existentes antes, passam a dar espaço à casualidade. Isso ocorre porque é o momento que a criança aprende a contar, abrindo assim, espaço para explicações atomicistas de fatos tangíveis.

A razão sob o aspecto dos experimentos e dos raciocínios lógicos tornam questionamentos palpáveis e instigam o olhar da comprovação e a curiosidade mais latentes. A noção de tempo, velocidade e espaço também se estabelece nessa fase, ajudando inclusive nos discursos sobre passado, presente e futuro.

RC: 105382

Disponível em: https://www.nucleodoconhecimento.com.br/psicologia/perspectiva-piagetiana 
c) Operações racionais: Essas racionalizações e operações de pensamento, após os sete anos, fazem parte de um nível superior atingido depois da primeira infância. Piaget (1999) diz que esse nível operatório da inteligência é a essência do desenvolvimento mental.

Uma operação - seja ela, lógica, aritmética, geométrica, mecânica, física ou outra - é psicologicamente, segundo Piaget (1999, p. 48), "uma ação (de reunir indivíduos ou unidades numéricas, deslocar, etc.) cuja origem é sempre motora, perceptiva ou instintiva". Logo, por volta dos nove anos, as crianças ampliam a compreensão de comprimento, volumes e peso, e, portanto, seu entendimento espacial e de mundo. É interessante observar que o autor reforça que os indivíduos não alcançam essas relações antes dessa idade, então é importante aguardar o tempo de maturação cognitiva para apresentar com mais ênfase essas relações simétricas. O mesmo ocorre com outros conhecimentos, e que é o que o estudioso salienta todo o tempo: existe um momento para tudo.

Piaget (1999, p. 52) cita que "o pensamento infantil só se torna lógico por meio da organização dos sistemas de operação que obedecem às leis de conjuntos comuns". Dessa forma, o sujeito passa a compreender o mundo pela perspectiva da seguinte conjunção:

- Composição: coisas (operações) podem se compor entre si e resultar numa outra; é a soma.

- Reversibilidade: coisas podem ser invertidas. Tem-se a subtração ou números positivos e negativos.

- Anulação ou emparelhamento: uma operação direta e seu inverso podem resultar em algo nulo ou idêntico. Piaget (1999, p. 52) dá o exemplo de +1-1=0.

- Associação: tudo pode associar-se entre si e de muitas maneiras através de agrupamentos.

RC: 105382

Disponível em: https://www.nucleodoconhecimento.com.br/psicologia/perspectiva-piagetiana 
O autor cita:

\begin{abstract}
Em outras palavras, as noções e relações não se podem construir isoladamente, mas constituem organizações de conjuntos, nas quais todos os elementos são solidários e se equilibram entre si. Assim, esta estrutura própria à assimilação mental de ordem operatória assegura ao espírito um equilíbrio bem superior ou da assimilação intuitiva ou egocêntrica, já que a reversibilidade, anteriormente adquirida, traduz um equilíbrio permanente entre a assimilação das coisas pelo espírito e a acomodação do espírito às coisas. (PIAGET, 1999, p. 52)
\end{abstract}

Em suma, o indivíduo vai aos poucos compreendendo a importância da individualidade e do grupo, assim como as leis de reciprocidade.

d) A afetividade, a vontade e os sentimentos morais: Os aspectos são de imensa importância, pois, cooperação e reciprocidade asseguram a evolução da autonomia e coesão. E se os primeiros sentimentos morais do indivíduo se originam na relação com seus pais, o estudioso elucida que eles podem se fortalecer na forma de obediência e submissão (heteronomia), e justamente por todo esse contexto de cooperação e respeito mútuo (e de grupo) ser fortificado no ambiente escolar. Ademais, o respeito à autoridade, às regras e à fundamentação do sentimento de amizade, amplia o respeito unilateral aos mais velhos, aos diferentes e diferenças, condutas e sensos morais, sociais e de justiça.

Sobre essa última, as crianças desenvolvem um grande sentimento e entendimento de igualdade. Contudo, Piaget (1999) alerta que se um sujeito perceber que foi injustiçado por um adulto, seja de forma involuntária ou imaginária, que a criança vitimada passa a dissociar justiça de submissão. Esse sentimento moral vai acompanhar esse indivíduo por toda a vida.

O autor é categórico em afirmar que a moral, enquanto coordenação de valores, se compara à uma outra equação lógica (ou grupamento lógico). Uma série de valores agrupados ao serem alavancados se organizam, e regulam-se, conforme a constituição do indivíduo (mas que pode ser mutável), produz uma regulação contínua

RC: 105382

Disponível em: https://www.nucleodoconhecimento.com.br/psicologia/perspectiva-piagetiana 
na forma de sistemas autônomos que é aquilo que efetivamente são os agrupamentos lógicos. Todos esses fatores são o que fortalecem a unicidade da cognição e do emocional na edificação do desenvolvimento psíquico.

Por fim, o sexto estágio é o de operações intelectuais abstratas da formação de personalidade, e inserção afetiva e intelectual na sociedade adulta: a adolescência. $O$ pesquisador discorre que as reflexões anteriores levam a crer que o desenvolvimento mental termina entre os onze e doze anos, e que a adolescência é apenas uma crise passageira por causa da puberdade que separa a infância da idade adulta. Mas para o autor, é nítido que os fatos conhecidos não esgotam a análise do que é a adolescência. Assim, diferente de uma criança, o adolescente constrói sistemas e teorias. Crianças não constroem sistemas, pois elas os têm no inconsciente, no sentido que apenas quem está de fora consegue perceber. Já o adolescente, tem interesse por problemas não naturais, sem relação com a realidade vivida. Sobre essa capacidade do adolescente, Piaget (1999, p. 58) comenta: "O que mais espanta, sobretudo, é sua facilidade de elaborar teorias abstratas. Existem alguns que escrevem, que criam uma filosofia, uma política, uma estética ou outra coisa. Outros não escrevem, mas falam". Logo, essa nova forma de pensar, com ideias gerais e abstratas, acontece de forma contínua, a partir do pensamento concreto da segunda infância.

Por volta de onze a doze anos efetua-se uma transformação fundamental no pensamento da criança, que marca o término das operações construídas durante a segunda infância; é a passagem do pensamento concreto para o 'formal', ou, como se diz em termo bárbaro, mas claro, 'hipotético-dedutivo'. (PIAGET, 1999, p. 58)

Até a idade de onze ou doze anos, as operações da inteligência infantil são concretas, que se referem à realidade e aos objetos que podem ser manipulados. Sobre isso, Piaget (1999, p. 59) diz: "Quando o pensamento da criança se afasta do real, é simplesmente porque ela substituiu os objetos ausentes pela representação mais ou menos viva, está se acompanhado de crença e equivalendo ao real". Por isso, de

RC: 105382

Disponível em: https://www.nucleodoconhecimento.com.br/psicologia/perspectiva-piagetiana 
acordo com o autor, crianças têm dificuldades em resolver problemas matemáticos na escola. Se crianças pudessem manipular os objetos, iriam racionalizar sem problemas. Mas, os enunciados matemáticos estão, por exemplo, no plano da linguagem, por isso é mais difícil.

Depois dos onze ou doze anos, o pensamento formal torna-se possível, mesmo sem o apoio de percepção, experiência ou crença. O teórico define o pensamento concreto como a representação de uma ação possível e o formal é definido como uma representação de ações possíveis. Conforme o autor, só depois que o pensamento formal começa, por volta dos onze ou doze anos, é que se torna possível a construção dos sistemas que marcam a adolescência. Essas operações formais permitem que o pensamento se destaque e se liberte do que é real, permitindo que as reflexões e teorias construam-se a seu modo.

Há um egocentrismo intelectual do adolescente, que o autor compara tanto ao lactente que entende o universo com a sua atividade corporal, como à primeira infância, que entende as coisas ao pensamento em formação. O egocentrismo metafísico, com o tempo, encontra equilíbrio entre o pensamento formal e a realidade. O autor explica que o equilíbrio acontece quando a reflexão compreende que sua função não é contradizer, e sim, se adiantar e interpretar a experiência, ultrapassando o pensamento concreto e englobando as construções indefinidas da dedução racional e vida interior.

A construção da personalidade implica na descentralização do eu que se integra em um tipo de programa de cooperação. Todo o desequilíbrio centralizará sobre ela própria. Logo, os planos de vida dos adolescentes são cheios de sentimentos generosos, de projetos altruístas, e ao mesmo tempo de inquietante megalomania e egocentrismo consciente. O adolescente coloca para si o papel essencial na salvação da humanidade e organiza seu plano de vida para isso.

RC: 105382

Disponível em: https://www.nucleodoconhecimento.com.br/psicologia/perspectiva-piagetiana 
Por fim, sobre o pensamento da criança, Piaget (1999) sustenta que ela começa sendo "pré-lógica" na necessidade de constituição contínua das estruturas lógicas, e pode adentrar o mundo do adulto ao final desse ciclo.

\section{EVOLUÇÃO PSìQUICA ATRAVÉS DO DESENHO}

Durante o percurso da História da Humanidade, o ser humano passou por um processo evolutivo que ficou registrado na Arte. Do princípio nas cavernas com as pinturas rupestres, as expressões de comunicação desenvolveram-se posteriormente de muitas formas, incluindo os grafismos dos fenícios e a Lei da Frontalidade dos egípcios. Mais tarde, adentrou-se o período dos desenhos mais encorpados e cheios de elementos da Idade Média, mas que não possuíam perspectiva, profundidade e proporções corretas. No Renascimento, após os estudos de Filippo Brunelleschi (FARTHING, 2011) que proporcionaram o surgimento da perspectiva, tudo mudou, e esse único e importante advento trouxe tamanha maturidade perceptiva (até em outras áreas de conhecimento), que acelerou as modificações de linhas de desenhos e uso de cores nos séculos seguintes.

A utilização de tratamento psicanalítico em crianças foi de grande resistência para Sigmund Freud (1972; apud MEREDIEU, 2000), até mesmo por sua compreensão de que crianças teriam muita dificuldade de comunicação. Somente com os trabalhos de Melaine Klein (1991-1997; apud MEREDIEU, 2000) é que os pequenos puderam ser atendidos pela psicanálise. E não foi algo fácil, pois, exigiu a criação de estatutos e métodos específicos para a fundamentação psicológica. Klein (1991-1997; apud MEREDIEU, 2000) criou a técnica do jogo, o que permitiu avaliar o lugar do desenho em um tratamento, e possuir os mesmos mecanismos de associação de discursos de um adulto. Os desenhos passaram a ser apresentados como uma atividade lúdica e inseridas nas brincadeiras, e foi dali que a psicanalista desenvolveu a expressão figurativa.

RC: 105382

Disponível em: https://www.nucleodoconhecimento.com.br/psicologia/perspectiva-piagetiana 
Após a abertura de possibilidades de trabalho com os infantes, vários analistas passaram a tratar crianças com materiais lúdicos e as representações através de desenhos. Eles acreditavam que os desenhos poderiam ser trabalhados juntamente com os sonhos, participando de dois níveis de expressão: "um consciente e mais ou menos intencional, e outro inconsciente e recorrendo a uma simbologia complexa" (MEREDIEU, 2000, p. 78). Posteriormente e em outros níveis de pesquisa, Piaget (1999) concluiu através de estudos comparativos com crianças de nacionalidades diferenciadas, que não existem diferenças fundamentais ao nível do grafismo de um local para outro. Entretanto, para alguns estudiosos isso pode variar de acordo com a civilização que o sujeito está inserido.

Crianças são espelhos daquele meio em que estão inseridas, e, sendo assim, os seus desenhos são reflexos de tudo aquilo que vivem e experienciam através de diversas informações da família, escola e sociedade em que estão firmadas. Meredieu (2000) completa que para se conseguir identificar um desenho, é necessário colocar-se diante da cultura do indivíduo, isentando-se da sua própria e junto com seus conceitos (e pré-conceitos). O que entra em jogo são as experiências, vivências e cultura do outro, levando-se também em conta a ordem biossocial. Além disso, conforme a autora, o que é raro aparecer nos desenhos infantis é a questão da sexualidade. Uma área que fica mais recalcada em suas expressões artísticas, afinal, estamos em uma sociedade mais reprimida. Contudo, isso emerge de forma contundente quando os pequenos sofrem algum tipo de abuso sexual.

De acordo com a autora, o desenho infantil nos últimos anos está retornando à indústria e à publicidade: seja em exposições, filmes, artigos livros e outros. Essa importância repentina gerou inúmeros mitos, tais como a espontaneidade infantil dando a entender que não se sabe a influência do meio no condicionamento do infante, mito da arte para essa faixa etária -, quando é evidente que as crianças estão aquém de qualquer pesquisa estetizante. A partir desses mitos, gerou-se uma enorme

RC: 105382

Disponível em: https://www.nucleodoconhecimento.com.br/psicologia/perspectiva-piagetiana 
quantidade de obras literárias preocupadas em interpretar, e assim, formar uma visão psicológica e psicanalítica, ou, estabelecer uma formação pedagógica.

A autora comenta que a vasta produção literária sobre o assunto, em sua maioria, só chegou em resultados fragmentados e que ainda falta uma síntese, mas que é difícil de se elaborar por causa da heterogeneidade dos instrumentos da análise. Atualmente, os estudos sobre o desenho infantil utilizaram-se da contribuição da obra do psicólogo Jean Piaget (1994; 1999) e prosseguem no sentido de uma ampliação dos mecanismos da expressão infantil. Assim, a contribuição dos psicólogos, segundo a autora, é inegável e ajudaram na colocação de conceitos básicos que permitiram a abordagem da mentalidade infantil. Antes, só se observava as particularidades do grafismo infantil que diziam respeito à mobilidade motora. Sobre essa interpretação, Meredieu (2006, p. 3) comenta que "Não existe visão verdadeira, e a visão adulta não pode de modo algum representar a medida padrão."

Hoje, no lugar dos desenhos serem definidos como erros, tem-se uma valorização às produções infantis. A autora também comenta que a originalidade da criança é difícil de mostrar já que a imitação do adulto tem um papel importante, e a leitura dos desenhos utilizam instrumentos criados pelos próprios adultos. Meredieu (2006, p. 3) afirma "Nunca será demais repetir: o meio em que a criança se desenvolve é o universo adulto, e esse universo age sobre ela da mesma maneira que todo contexto social, condicionando-a ou alienando-a". Ou seja, estudar as produções infantis sem considerar a influência e pressão adulta levará à uma leitura equivocada.

Concebido pelo desenvolvimento da função simbólica na criança, a evolução do desenho, para a autora, depende da evolução da linguagem e da escrita. Essa escrita exerce uma fascinação sobre a criança, antes mesmo de que ela própria possa traçar seus traços: Muito cedo, ela imita a escrita dos adultos, como observa Meredieu (2006, p. 10-11), "Geralmente é entre os três e quatro anos que a criança produz essa escrita fictícia, traçada em forma de dentes de serra, e carregada para ela de uma fabulosa

RC: 105382

Disponível em: https://www.nucleodoconhecimento.com.br/psicologia/perspectiva-piagetiana 
polissemia [...]". A autora também comenta que quando a criança atinge a idade escolar existe uma diminuição na produção dos desenhos, já que a escrita ocupa mais a atenção. Com a escrita a criança descobre novas possibilidades de grafia e o desenho e a escrita podem se confundir ou se misturar, já que o que separa o desenho da escrita é um limite flutuante.

\subsection{DESENHOS NO PROCESSO DE MATURIDADE PSICOLÓGICA DO INDIVÍDUO}

O desenho infantil pode ser considerado uma forma de linguagem, mesmo sendo hipotético e até mesmo metafórico. Este tipo de linguagem deve ter um sistema a ser seguido, para que possa ser decifrado de forma correta.

A forma de se desenhar e a forma como o desenho evolui é inteiramente ligado à evolução psicomotora, e é de fato muito importante ter sempre em mente que a criança está em perpétua mutação. Luquet (1969) explica que tudo o que diz respeito à criança, como por exemplo suas experiências, forma de crescimento, sentimentos, hábitos e outros fatores, interferem diretamente na evolução dos signos de linguagem. Quando o infante está zangado, faz rabiscos de forma enérgica. Quando o desenho é de um personagem, como por exemplo o irmão ou a irmã, cuja existência é indesejada, o traço acaba sendo mais rudimentar.

Acontece com o desenho, o mesmo que nos filmes. É uma sucessão de fatos, que dependem inteiramente um do outro para terem sentido, funcionando como se houvesse uma continuação de circunstâncias. No desenho infantil, uma casa não é necessariamente uma casa, pode ser também um corpo, um rosto, uma chaminé, um nariz, entre outras milhares de coisas. Assim, Luquet (1969) divide a evolução do grafismo em quatro estágios. O primeiro estágio é chamado de Realismo Fortuito, que se inicia por volta dos dois anos e finaliza o período de rabisco da criança. Por fim, a criança começa a fazer uma ligação entre seus traços e as figuras, conseguindo dessa

RC: 105382

Disponível em: https://www.nucleodoconhecimento.com.br/psicologia/perspectiva-piagetiana 
forma começar a dar nome às figuras. O segundo estágio ocorre entre os três e quatro anos, e é chamado de Realismo Fracassado, em que a criança começa a querer copiar as figuras, passando por uma série de fracassos e sucessos na realização do desenho.

A terceira etapa é chamada de Realismo Intelectual, tendo como idade principal desta etapa os quatro anos de idade, mas, podendo se estender até os dez ou doze anos de idade da criança. A principal característica desta fase, é o fato de a criança não desenhar o que ela vê e sim o que ela sabe desenhar. Normalmente os desenhos são em plano deitado, ou seja, eles são feitos em uma folha deitada e com base num eixo central. Ademais, ocorre a transparência, como quando um bebê é desenhado no ventre da mãe. Por último, na quarta fase, tem-se o Realismo Visual, que é geralmente por volta dos doze anos, porém, pode ocorrer a partir dos oito anos, que basicamente dá início aos desenhos de âmbito mais adulto, e com uma perspectiva mais realista.

Luquet (1969) e apoiado por Meredieu (2000) citam que o grafismo se inicia através dos rabiscos, gesto basicamente motor. Muitas vezes, o rabisco é considerado algo fútil, e habitualmente é ignorado. A transparência na fase infantil representa um tipo de experiência que não foi tão especial ou afetiva. Pode-se enxergar a evolução da criança quando se inicia no chamado desenho informal, através dos borrões, aglomerado, rabisco sendo ele em movimentos giratórios ou oscilantes.

Primeiramente, a criança projeta no desenho seu próprio esquema corporal; ela traduz assim a maneira como vive seu corpo e se sente apreendido pelo outro, como aquela menina cujo desenho, boneco invertido, correspondia à sua posição favorita, deitada no chão, de pernas para o ar. Ou aquela outra menina sentindo uma dor física que não consegue localizar conscientemente, mas que exprime de imediato deformando o lado de uma casa. (MEREDIEU, 2000, p. 32)

Normalmente as crianças tendem a desenhar o Sol, bonecas, casas, navios, por exemplo. O tema do desenho não é o mais importante. Os desenhos infantis iniciamse de forma simples com círculos, quadrados, triângulos, imagens como "V" e outros.

RC: 105382

Disponível em: https://www.nucleodoconhecimento.com.br/psicologia/perspectiva-piagetiana 
Quando essas formas são combinadas, transformam-se em desenhos, e consequentemente, em vocabulário de desenho infantil. Meredieu (2000, p. 16) ainda completa: "Nunca será demais sublinhar: toda tentativa para incluir o estudo do grafismo infantil no quadro de uma semiologia defronta-se com dificuldade quase insuperáveis, e nesse terreno, cor, vêm dar mostras de prudência até excessiva."

A construção espacial de representação dos desenhos, independentemente se for olhada pelo contexto global da humanidade ou para a criança que um dia se tornará um adulto, apresenta toda uma evolução através de estágios. Na virada do século $\mathrm{XXI}$, a autora considera a pedagogia e o ensino atrasados em relação a Arte e a publicidade, já que essas últimas se utilizam com propriedade da exploração e descoberta de espaços diferenciados do campo perceptivo. Assim, o entendimento de ocupação espacial varia conforme as condições sócio-históricas de um determinado momento.

Segundo a autora, o campo espacial e sensorial sofre uma constante estruturação e produz diferentes processos perceptivos em adultos e crianças. Exatamente por isso, no princípio, um indivíduo não possui nenhuma noção de espaço, mas aos poucos ele elabora a concepção espacial. Ela respalda-se em Luquet (1969; apud MEREDIEU, 2000) para relatar que inicialmente tem-se os espaços representativos, que são vitais e afetivos. Primeiro, ocorre um estágio embrionário e vegetativo ligado às sensações de prazer e desprazer. No segundo momento, surge o estágio sensório motor que é ligado aos movimentos iniciais corpóreos que incitam até o caminhar.

Dos espaços representativos, a criança evolui para o espaço figurativo, depois o espaço perceptivo, e no final, o espaço gráfico. O espaço gráfico corresponde ao espaço do gesto e de todos que participam da vida do sujeito para que ele possa representar aqueles primeiros traços sem forma, seja em manchas ou rabiscos. Mesmo nesses rabiscos já existe uma tentativa de modulação espacial através dos próprios vazios e preenchimentos, e até pelo posicionamento na folha (central, RC: 105382

Disponível em: https://www.nucleodoconhecimento.com.br/psicologia/perspectiva-piagetiana 
transpassando os limites do papel ou nas extremidades). (LUQUET, 1969; MEREDIEU, 2000)

No plano gráfico, a organização espacial é orientada por relação de continuidadedescontinuidade, conforme Meredieu (2000). Quando o pequeno efetivamente começa a desenhar, suas primeiras estruturas não estão conectadas aos sistemas métricos, mas às noções qualitativas e afetivas. É também nessa fase que as crianças desenham figuras dentro de outras figuras. A grandeza representada nos desenhos é afetiva, e proporções ampliadas de objetos e pessoas ganham forte valor emocional. Portanto, aos poucos o sujeito vai elaborando espaços coerentes, e eles tentam representar suas vivências. A folha de papel é o espaço a se dominar. Com a evolução das garatujas para figuras com forma, posteriormente ocorre também o acréscimo de cenários e até preenchimentos de outras estruturas com árvores, animais e até paisagens com chuva e céu, por exemplo. A autora ainda explica que para representar espaços, crianças utilizam-se de traços rudimentares e acompanhados de dois processos: o plano deitado e a transparência.

Os pequenos ignoram o espaço projetivo por não compreenderem os desdobramentos do plano. Dessa forma, representam suas imagens como se fosse um grande chapado esparramado no chão. É como se tudo estivesse deitado. A escritora cita o plano deitado irradiante para denominar esse tipo de representação, assim como o axial quando os desenhos são mais complexos e se entremeiam. Contudo, outros indivíduos conseguem representar desenhos duplicados de plano deitado que a autora chama de reflexo. A criança tenta representar os dois lados e um mesmo objeto, mas o faz como se fosse algo se refletindo em um espelho d'água. Meredieu (2000, p. 48) diz que "a profundidade de campo é substituída pela sobreposição e o escalonamento dos planos". Objetos como casas, árvores e estradas podem ser representados no papel como se serpenteando espaços acima do desenho de base inferior.

RC: 105382

Disponível em: https://www.nucleodoconhecimento.com.br/psicologia/perspectiva-piagetiana 
Aos 8 ou 9 anos, o sujeito adquire os mecanismos euclidianos e de relações projetivas com grandeza e forma. Assim, ele consegue a partir desse momento, criar espaços topológicos que são um tanto deformados, como um campo de futebol visto do alto. Nesse período de relação topológica, a casa possui grande importância nas representações na infância. Ela é um prolongamento do corpo e da personalidade da criança, e toda essa dinâmica é apoiada por outros autores como John Buck (2003), Maria OCampo, et al. (2005) e Maria Retondo (2000). Conforme Luquet (1969) e Meredieu (2000), a casa funciona como espaço mítico para projeção de angústias e fantasias. Assim, casas podem ser representadas de duas formas:

- A casa tradicional, com linhas retas e geométricas, apresentando telhado pontudo e na maioria das vezes com chaminé, estradinha e até elementos do gosto pessoal.

- Casa dos sonhos, que fazem parte da imaginação da criança e se apresentam na estrutura de fachada e interior completamente diferentes da tradicional. As formas são totalmente inusitadas, até com espaços esféricos.

Meredieu (2000) diz que as formas esféricas acalmam e tranquilizam os indivíduos, pois trazem a lembrança inconsciente da matriz inicial: o útero. Da mesma forma, crianças trariam essa lembrança, mesmo a casa sendo em linhas tradicionais, pois elas costumam sempre representar água ou um lago próximo à construção. Outros simbolismos podem ser identificados como montanhas ou muralhas que mostram o sentido de proteção, e vinculados à simbologia feminina do materno; a segurança do primeiro lar do ser humano. Quanto a Piaget (1994; 1999; apud MEREDIEU, 2000), ele distingue três fases de evolução do espaço:

Incapacidade sintética: o espaço não possui relações projetivas e euclidianas, além da inexistência de profundidade ou grandeza. As topologias ainda estão se organizando. Personagens possuem dois braços, mas ficam de um mesmo lado do

RC: 105382

Disponível em: https://www.nucleodoconhecimento.com.br/psicologia/perspectiva-piagetiana 
corpo, assim como a cabeça é colada ao corpo (sem pescoço). Olhos e boca podem encontrar-se fora do lugar.

Realismo intelectual (de 4 a 10 anos): as relações projetivas e euclidianas começam a se elaborar, mas são contraditórias. Ademais, as reações topográficas apresentam uma disposição mais respeitadas, mas, se chocando com o espaço perspectivo. Rostos são representados de perfil, com os dois olhos do mesmo lado (como a personagem de desenho animado Peppa Pig). Distâncias, coordenadas e perspectivas não estão presentes. Estradas se apresentam em linhas paralelas; figuras humanas possuem sempre o mesmo tamanho, perto ou longe, e os planos deitados também se fazem presentes.

Piaget (1994; 1999; apud MEREDIEU, 2000) explica que crianças levam muito tempo para representar corretamente pontos de vista com perspectiva (mesmo tendo o plano perceptivo desde cedo), pois existe uma diferença entre visão e representação perspectiva.

Para considerar um objeto de determinado ponto de vista, não é necessário estar consciente dele. Em compensação, 'representar-se ou representar graficamente o mesmo objeto em perspectiva, supõe que se tem consciência, simultaneamente, do ponto de vista sob o qual é percebido e das transformações devidas à intervenção desse ponto de vista'. Portanto, o que permite a figuração da perspectiva é a apreensão de uma relação entre o sujeito e o objeto observado. (PIAGET e INHELDER, 1948, p. 211; apud MEREDIEU, 2000, p. 57)

Realismo visual (inicia entre 8 e 9 anos): com relações topográficas constituídas, as distâncias, e, projeções perspectivas e projetivas passam a se harmonizar e se fazer presentes.

Outros dois autores que falam sobre esta última etapa do desenho infantil como Estágios do Realismo, são Lowenfeld e Brittain (1977). Eles explicam que esta fase se inicia aos nove anos e estende-se até aos doze. Nela, segundo os autores, o desenho tem uma maior representação do real apesar de ainda ter simbologia, e a

RC: 105382

Disponível em: https://www.nucleodoconhecimento.com.br/psicologia/perspectiva-piagetiana 
autocrítica do sujeito em relação aos seus desenhos é bem maior. Além disso, nessa última fase, a criança está mais detalhista, e, também, percebe-se integrante de uma sociedade, começando a explorar seus pensamentos sobre o mundo. Sobre o desenho infantil, os autores confessam que não é fácil perceber a transição das etapas e que elas não ocorrem na mesma fase ou da mesma maneira para todas as crianças.

Através dos signos presentes nos traços, formas, elementos e cores, um psicólogo bem treinado pode perceber e entender muito além do que os grafismos configuram como representatividade do eu. O estado emocional do indivíduo comumente se apresenta, e pode ser detectado em cada elemento. Contudo, muitos pesquisadores no passado (e pioneiros no assunto) analisaram de forma errônea e limitada esse entendimento que abrange uma totalidade de conduta muito maior:

Descrito como mais ou menos forte, agressivo ou hesitante, o traço deu ocasião a estudos minuciosos, como os empreendidos por Alschuler e Hattwick que chegaram a uma tipologia sumária: linhas curvas e sinuosas nos indivíduos sensíveis e temerosos; ângulos retos, linhas firmes nos opositores e realistas. (MEREDIEU, 2000, p. 57)

Esta citação mostra a preocupação da autora sobre o equívoco da tentativa de leitura dos pioneiros nesse tipo de análise por ser limitada, contudo, foi um início muito importante, e outros que vieram depois, ampliaram a reflexão:

A escolha do formato e a amplitude da superfície recoberta testemunham o maior ou menor domínio do sujeito, suas inibições ou distúrbios. A repetição obsedante e sistemática de um mesmo motivo sobre toda a folha traduz um temperamento obsessivo e compulsivo; a criança tímida e introvertida desenha-se minúscula no centro da página, enquanto a instável preenche toda a superfície com traços nervosos. (MEREDIEU, 2000, p. 63)

A escritora também detalha que até o uso do espaço da folha defendido por alguns especialistas apresentariam características contestáveis sobre a personalidade do indivíduo, já que até mesmo o uso de colorações estaria ligado a interpretação cultural de onde o sujeito estivesse inserido.

RC: 105382

Disponível em: https://www.nucleodoconhecimento.com.br/psicologia/perspectiva-piagetiana 
Conviria acrescentar qualquer simbologia universal, pois existe uma simbologia espacial, mas ao mesmo tempo individual e cultural. Encontramos aqui as observações de Freud sobre a impossibilidade de se constituir uma chave universal dos sonhos, já que 0 deciframento do sonho evoca uma simbologia que mergulha suas raízes na própria vida do sonhador. Não se poderia, pois, utilizar uma chave semelhante para interpretar o desenho. (MEREDIEU, 2000, p. 63)

Ela igualmente explica que geralmente ignoram a leitura do uso das cores nas análises de desenhos. Conforme elucida, o hábito de generalização (até firmado por estudos contraditórios), ainda é muitas vezes taxativo e equivocado. A escolha do uso de determinadas cores por um indivíduo é subjetiva, dependendo ainda de sua cultura e vivências, e, portanto, ligada ao sensorial e racional, não podendo ser sistemática na interpretação de terceiros.

A utilização das bases de grafismo a partir de desenhos como diagnóstico, são sequenciados por dois parâmetros: testes de inteligência e testes de personalidade.

Testes de inteligência: Conforme Meredieu (2000), testes de desenhos determinam o grau de maturação intelectual de um indivíduo, ou seja, estabelecem em que fase de idade mental o indivíduo se encontra, e se está compatível com sua idade cronológica de desenvolvimento. Nesses testes, detecta-se até mesmo sinais de debilidades e doenças mentais. Pede-se nesse processo, que a criança reproduza figuras geométricas e humanas, e até desenhos de imaginação.

Testes de personalidade: Sendo os desenhos de um indivíduo seu reflexo de personalidade, o valor projetivo nesse teste é de suma importância. Cada tema configura um teste e poderoso leitor simbólico do que está inserido em cada desenho. Os desenhos requisitados são pedidos na forma individual de árvores, figuras humanas e até desenhos livres.

A composição da família, a ordem de aparecimento dos personagens, a estatura destes, os comentários que acompanham seu aparecimento, tudo será cuidadosamente observado no decorrer da

RC: 105382

Disponível em: https://www.nucleodoconhecimento.com.br/psicologia/perspectiva-piagetiana 
execução; em geral o personagem mais importante é desenhado primeiro, seu tamanho é consequência disso - mas é preciso desconfiar destes dados gerais, pois o contexto clínico pode muito bem lançar por terra esta constatação; a ausência de um personagem, irmão ou irmã que a criança gostaria de excluir da família, revela-se na maioria das vezes como o sinal mais pertinente. Mas como observa adequadamente Widlocher, convém 'tomar cuidado para não ir demasiadamente longe na interpretação destas anomalias (...) o desenho da família ensina-nos mais sobre a existência dos conflitos do que sobre sua natureza'. (MEREDIEU, 2000, p. 72)

Portanto, é fato que desenhos refletem inibições, distúrbios de inteligência e comportamento. Entretanto, a escritora pondera com uma crítica e preocupação com relação a como são desenvolvidos os estudos de análise e dos próprios métodos empregados, tornando tudo ilegível e/ou mascarando resultados. Isso pois, os testes seriam todos padronizados para encaixar os indivíduos em resultados já préestabelecidos e que depende da interpretação de um adulto. Por estes fatores, a especialista entende que existem limites na contribuição da Psicologia projetiva e sob as metodologias aplicadas. Ela cita que "se o desenho é para ser lido, é como totalidade, expressão de um desejo da criança na série completa não somente de suas transformações, mas também de suas elisões" (MEREDIEU, 2000, p. 73).

Em sua obra, Luquet (1969) aponta que o motivo pelo qual a criança desenha, é divertir-se. Ela desenha tudo que faz parte de sua experiência e as coisas que a rodeiam, por isso é tão comum a figura humana em suas obras. Para o autor, à medida que a criança vai envelhecendo, começa a prestar e a incluir mais detalhes em seus desenhos.

\subsection{MATERIAIS GRÁFICOS E DE ARTE NO UNIVERSO TERAPÊUTICO}

Este trecho de seção apresenta um sucinto resumo sobre a utilização de materiais gráficos e artísticos muito específicos. Serão explanados somente aqueles que foram apresentados de forma efetiva durante a pesquisa com os voluntários; isso pois, a

RC: 105382

Disponível em: https://www.nucleodoconhecimento.com.br/psicologia/perspectiva-piagetiana 
variedade desses materiais é enorme, e o intuito deste artigo não é se concentrar nisso. Contudo, a exposição desses poucos elementos específicos, ajudaram até mesmo na amplitude de entendimento para as análises dos desenhos.

Conforme Carrano e Requião (2013), apesar dos materiais utilizados para arte já serem conhecidos há muitos séculos por artistas e professores, hoje tomaram novas possibilidades através de terapeutas. Cada um desses aparatos possui uma forma expressiva e diferenciada muito própria, até por suas características e propriedades que vão da química, da variação de tamanho à dureza. Desta forma, cada material reproduz uma linguagem específica e igualmente conduz a uma resposta diferente carregada de conteúdo emocional.

As imagens comunicam-se por si mesmas, assim como, seus detalhes e elementos, como bem apresentado por Buck (2003), Ocampo, et al. (2005), Retondo (2000), Meredieu (2000), Lowenfeld e Brittain (1977) e Luquet (1969), mas o elemento empregado produz um diálogo expressivo que para um leigo passa despercebido. Muito mais do que uma reprodução pictórica ou de expressão artística, a associação em conjunto dos materiais com o desenho em si, reproduzem toda uma construção (ou reconstrução) do psiquismo do indivíduo.

Carrano e Requião (2013) dizem que o papel, por exemplo, não é apenas um suporte para a expressão de um desenho. Alguns pesquisadores, como os citados neste artigo, associam a posição vertical ou horizontal de seu uso escolhido pelo indivíduo, com uma ligação direta com o feminino e o masculino. Horizontalidade estaria ligada ao feminino, ao conforto e à segurança. Talvez isso explicasse o porquê crianças gostam tanto de utilizar o papel nessa posição. Já na vertical, haveria uma relação com o masculino, o fálico, ao crescimento. $O$ fato é que isso não pode ser interpretado literalmente, nem como regra, pois o indivíduo pode encarar apenas como qual o melhor espaço para inserir aquilo que se propõe em seus desenhos.

RC: 105382

Disponível em: https://www.nucleodoconhecimento.com.br/psicologia/perspectiva-piagetiana 
Conforme as autoras, a borracha pode ser vista também como um elemento de tentativa de reestruturação de caminhos, de ponderações diante de escolhas. Materiais como lápis de grafite e lápis de cor, por estarem em invólucros rígidos de madeira, assim como a caneta hidrográfica (igualmente em um envoltório de plástico enrijecido), produzem traços rígidos e permitem precisão. Por outro lado, eles não possibilitam que o indivíduo entre em contato direto com o pigmento, o que se diferencia com o uso do lápis de cera, pastéis e até carvão.

Carrano e Requião (2013) afirmam que os estudos feitos nos últimos anos por terapeutas e pesquisadores mostram que os sujeitos entram mais efetivamente em conexão com o que reproduzem, ao utilizarem materiais em contato direto com pigmentos. Isso ocorreria porque o indivíduo não poderia evitar sujar-se com os pigmentos e esses ao aderirem a pele, criam não só a interação entre o sujeito e sua reprodução, mas ele não poderia manter o controle de afastamento. Desta forma, as funções emocionais são mais controladas no uso do lápis e hidrográfica, e com isso, o emocional através do inconsciente não emerge em sua totalidade.

Como material gráfico, o lápis de grafite apresenta-se de forma rígida (mas, variando o grau de dureza e maciez), em invólucro de madeira (muito comum) ou em bastão puro (esse, utilizado por artistas, designers e arquitetos). Por essa característica, terapeutas utilizam esse material para trabalhar limites, atenção, organização e concentração de um indivíduo. Segundo as autoras, o grau de variação de dureza ou maciez desse grafite é conseguido através da mistura de argila cerâmica com grafita. Quanto maior a quantidade de argila cerâmica, maior será a dureza. Essa mistura acaba não só gerando diferença na rigidez do traço, mas igualmente na textura, largura da linha e na diferença de luz e sombra para efeitos mais claros ou escuros. Logo, o lápis ajuda no processo de concentração e coordenação motora-fina, de conter e redefinir limites. Ademais, pessoas que utilizam esse material tendem a expressar-se e organizar melhor seus sentimentos e a sua vida, pois ele funciona de

RC: 105382

Disponível em: https://www.nucleodoconhecimento.com.br/psicologia/perspectiva-piagetiana 
base como um esboço para construção de algo mais concreto. Dessa forma, o material também evoca memórias guardadas. (CARRANO e REQUIÃO, 2013)

Tanto professores, quanto terapeutas, podem utilizá-lo para alterações de comportamento já instituídos. As autoras exemplificam que as pessoas que gostam de estar no controle, não ousam e gostam de manter-se na segurança da mesma situação. No caso, o terapeuta começa a trabalhar com lápis (pela semelhança rígida com o próprio indivíduo), e aos poucos evolui de forma progressiva e proporcional aos outros materiais mais maleáveis. Nesse sentido, as autoras frisam que nunca se pode começar com um material inverso ao psiquismo do sujeito. Indivíduos muito rígidos e com dificuldades de lidar com limites, tendem a apresentar resistência ao uso de qualquer tipo de material, mas sobretudo os mais maleáveis.

O lápis de cor trabalha os mesmos pontos psíquicos que o lápis de grafite, possuindo apenas a diferenciação das cores nas minas, que criam um grande apelo aos sentimentos e emoções. Sua constituição difere um pouco do grafite, pois tem-se argila, pigmento colorido, cera e aglutinante. Carrano e Requião (2013) afirmam que o lápis de cor (apesar de estar no mesmo patamar de rigidez que o lápis de grafite), é compreendido por terapeutas como um material intermediário, pois facilita a passagem da linguagem dos materiais gráficos (grafite) e de desenhos, permitindo que exista uma aproximação das tintas. Isso ocorre pela própria fluidez que a coloração vai permitindo. Portanto, funcionam como uma ponte entre o estado rígido e o maleável, e até por se permitir ultrapassar os limites impostos pelo traço do grafite.

Nesse processo evolutivo do lápis de cor para as tintas, ainda haveria o lápis de cor aquarelável, que trabalha a passagem de fronteiras através da água, o que em nível terapêutico auxilia nos processos de passagem e mudança de hábitos. A escritoras explicam que, por exemplo, pessoas demasiadamente organizadas, controladoras e limitadas irão respeitar os limites do desenho no simples pintar com o lápis de cor. Contudo, ao utilizarem o pincel molhado, costumam frustrar-se com a falta de controle

RC: 105382

Disponível em: https://www.nucleodoconhecimento.com.br/psicologia/perspectiva-piagetiana 
que aquilo gera. Para evitar esse impacto imediato, as primeiras formas devem ser abstratas e induzidas como brincadeira, para que ao se depararem com seus próprios desenhos, evoluam na tentativa de exploração e encarem as mudanças que não podem ser controladas. O oposto com indivíduos demasiadamente expansivos, também pode ser feito. As autoras explicam que primeiro elabora-se uma aguada de anilina no papel, o que gera manchas disformes. Depois o indivíduo precisa desenhar com o lápis aquarelado sobre as manchas molhadas, forçando no ato do desenho que linhas limites surjam ali.

Sobre a caneta hidrográfica, além de ser igualmente um material intermediário, Carrano e Requião (2013) dizem que esse elemento deixa os contornos bem definidos e não permite a diferenciação de nuances. Por causa disso, delimita fortemente espaços e demarca permanência, já que o desenho não pode ser desfeito. Ainda conforme as autoras, o lápis de cera, também como material intermediário, é uma barra de cera com pigmentos coloridos. Seu formato espelha e induz segurança ao indivíduo, pois permite firmeza no traço, liberdade de movimento e contato direto com o material. Todos esses fatores são facilitadores no processo expressivo.

Enfim, cada material produz um efeito e fala sobre o indivíduo, e que agregado ao desenho por ele mesmo, possibilita a leitura sobre o estado psicológico desse sujeito.

\section{PERCEPÇÕES, EXPLICAÇÕES E ANÁLISES DOS DESENHOS}

Quatro voluntários participaram da pesquisa: um menino de oito anos, uma jovem de quinze anos, um bebê de dois anos e uma menina de nove anos.

Para dar andamento aos procedimentos de coleta dos desenhos, foram oferecidos para esses quatro indivíduos, folhas de papel A4 em sulfite, borracha, lápis de grafite preto B2, lápis de cor (com 12 cores), e canetinhas hidrográficas.

RC: 105382

Disponível em: https://www.nucleodoconhecimento.com.br/psicologia/perspectiva-piagetiana 
Os menores foram sondados em seu próprio ambiente doméstico. Os locais eram tranquilos e as crianças apresentavam calma e conforto. Assim, foi requisitado que cada uma fizesse um desenho livre, da sua escolha.

Então, antes de dar início à próxima seção de análise dos desenhos, cabe ressaltar e lembrar que a verificação aqui não é dentro do rigor da técnica do HTP (BUCK, 2003; OCAMPO, et al., 2005; RETONDO, 2000), mas apenas um cruzamento de interpretação entre as teorias de Piaget (1994; 1999), Lowenfeld e Brittain (1977) e Luquet (1969).

\subsection{CRIANÇA VOLUNTÁRIA 1 (LD):}

Idade: 08 anos / Escolaridade: $3^{\circ}$ ano do ensino fundamental / Materiais utilizados: Lápis de grafite, caneta hidrográfica, lápis de cor e papel.

Figura 1 - Desenho de LD: 8 anos

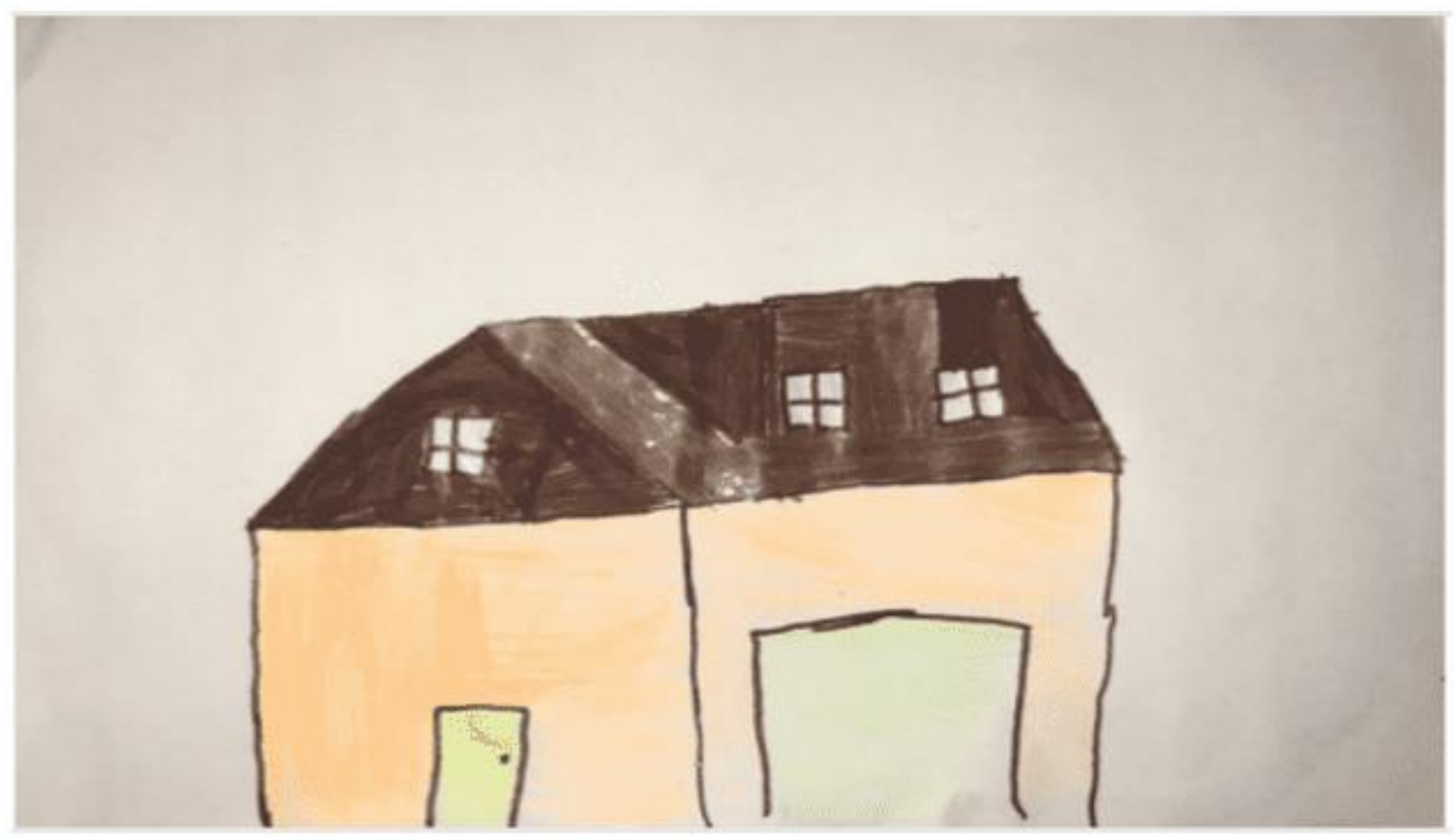

Fonte: arquivo de pesquisa da equipe.

RC: 105382

Disponível em: https://www.nucleodoconhecimento.com.br/psicologia/perspectiva-piagetiana 
De início, a criança ficou bem confusa sobre o que desenharia, e perguntou diversas vezes se ela poderia desenhar o que quisesse. Na hora de iniciar o desenho, começou com lápis, depois perguntou na sequência, se ele poderia contornar com canetinha, pois, segundo ele, fica mais bonito. Contornou, depois pintou as áreas com muita calma utilizando a própria caneta hidrográfica. Após o término do desenho, o menino demonstrou bastante felicidade em poder ter colaborado no trabalho de pesquisa.

Analisando o desenho a partir dos traços e materiais, vê-se que a criança desenhou uma casa que toma quase toda a proporção da folha e sem apresentar um chão (o limite da folha foi tomado como piso). As linhas saem da folha como se estivessem em continuidade. As paredes apresentam uma única porta como se fosse de entrada (com maçaneta) e um espaço aberto que aparenta ser uma garagem. As janelas (três ao todo) não estão representadas no corpo das paredes, mas no telhado. Não existe nada como cenários apoiadores, personagens (como animais) ou figuras humanas presentes. No contexto geral, a casa apresenta um esforço de ser apresentada em perspectiva, tentando criar uma noção de profundidade e distância.

O voluntário se encaixa na quinta fase estrutural de desenvolvimento de Piaget (1999), que é a infância, e, portanto, ele está construindo novas relações sociais para a formatação e construção das interações cognitivas e de sociabilização. Apesar de não haver cenário ou personagens no contexto geral, existe uma tentativa de perspectiva mais realista da casa, o que se encaixaria com o realismo visual descrito pelo autor. As relações topográficas sinalizadas por Luquet (1969) e Meredieu (2000) parecem estar em tentativa de construção, até pelo ensaio de projeção perspectiva e projetiva que tenta se fazer presente. Ademais, como apontado por Piaget (1994; 1999; apud MEREDIEU, 2000), a casa nesse período de relação topológica, possui grande importância por ser um prolongamento do corpo e da personalidade da criança, funcionando como espaço mítico para projeção de angústias e fantasias.

RC: 105382

Disponível em: https://www.nucleodoconhecimento.com.br/psicologia/perspectiva-piagetiana 
O desenho da criança encontra-se no período do Estágio Esquemático citado por Lowenfeld e Brittain (1977), no qual eles afirmam que a criança desenha de maneira mais organizada, com a descrição do momento em que ela está passando, e que geralmente contém linhas retas. Essa ponderação dos autores se encaixou com o desenho aqui apresentado (uma casa), pois, segundo a própria criança, ela tinha mudado a pouco tempo de uma casa para um apartamento, e assim, contém muitas linhas retas (a parede, o teto e a estrutura da casa: tudo está em linhas retas). Ele descreveu o momento que tinha acabado de passar, e retratou as linhas retas para construir a casa.

A criança voluntária também estaria dentro da terceira etapa de evolução do grafismo de Luquet (1969; apud MEREDIEU, 2000): o realismo intelectual (dos quatro anos, mas, podendo estender-se até os dez ou doze anos de idade). A principal característica dessa fase, é o fato de a criança não desenhar o que ela vê, e sim, o que ela sabe desenhar. Normalmente os desenhos são em plano deitado, mas, isto é mais perceptível quando a reprodução possui figuras humanas. Portanto, como o voluntário representou somente a casa, não é possível fazer essa análise.

O menino escolheu o uso do papel na horizontal, e que conforme Carrano e Requião (2013), é indicador de busca de segurança e proteção por aconchego ligado ao feminino. É bom ressaltar que Meredieu (2000) discorda dessa análise psicológica a partir do posicionamento de papel.

O voluntário escolheu usar para a construção do desenho, lápis grafite e lápis de cor e caneta esferográfica; tudo sem o apoio de borracha. No desenho, o uso do lápis de grafite foi apenas como base, pois depois foi recoberto com caneta hidrográfica para demarcação de espaço e limites bem definidos e isentos de dúvidas. A caneta hidrográfica foi utilizada para cobrir todo o telhado, além de servir de reforço nos traços. Como material intermediário, Carrano e Requião (2013) dizem que esse elemento demarca permanência no psiquismo, já que o que está ali, não pode ser

RC: 105382

Disponível em: https://www.nucleodoconhecimento.com.br/psicologia/perspectiva-piagetiana 
desfeito. Além disso, o telhado é proteção, é o teto sobre nossas cabeças, e somente ele teve preenchimento por esse material.

A pintura das paredes e porta foi feita com lápis de cor. Tanto com o lápis de cor, quanto com a caneta hidrográfica, a criança tentou preencher todos os espaços, mesmo que de forma aleatória, para deixá-la inteira, compactada. Esse preenchimento tentou se manter dentro dos limites dos traços de contorno, denotando alguém que precisa ou gosta de seguir regras.

O que chamou muito a atenção foi o reforço da caneta hidrográfica no telhado, o pouco uso de cores (sendo que havia um kit completo tanto desse material, quanto de lápis de cor), e a ausência de qualquer outro elemento além da própria casa.

A análise nos materiais utilizados pelo voluntário não pôde ser mais aprofundada, já que houve limitação de livre escolha de material. Ademais, como já salientado na seção anterior, o intuito da pesquisa não era para o enfoque do detalhismo do teste de HTP (BUCK, 2003; OCAMPO, et al., 2005; RETONDO, 2000). Contudo, da união do desenho com o material, e mais os conhecimentos baseados nas fases de desenvolvimento de Piaget (1994; 1999), o grupo de estudo conseguiu identificar esses pontos explanados.

\subsection{CRIANÇA VOLUNTÁRIA 2 (LS):}

Idade: 15 anos / Escolaridade: $1^{\circ}$ ano do ensino médio / Materiais utilizados: Lápis de grafite, lápis de cor (quatro cores), borracha e papel.

RC: 105382

Disponível em: https://www.nucleodoconhecimento.com.br/psicologia/perspectiva-piagetiana 
Figura 2 - Desenho de LS: 15 anos

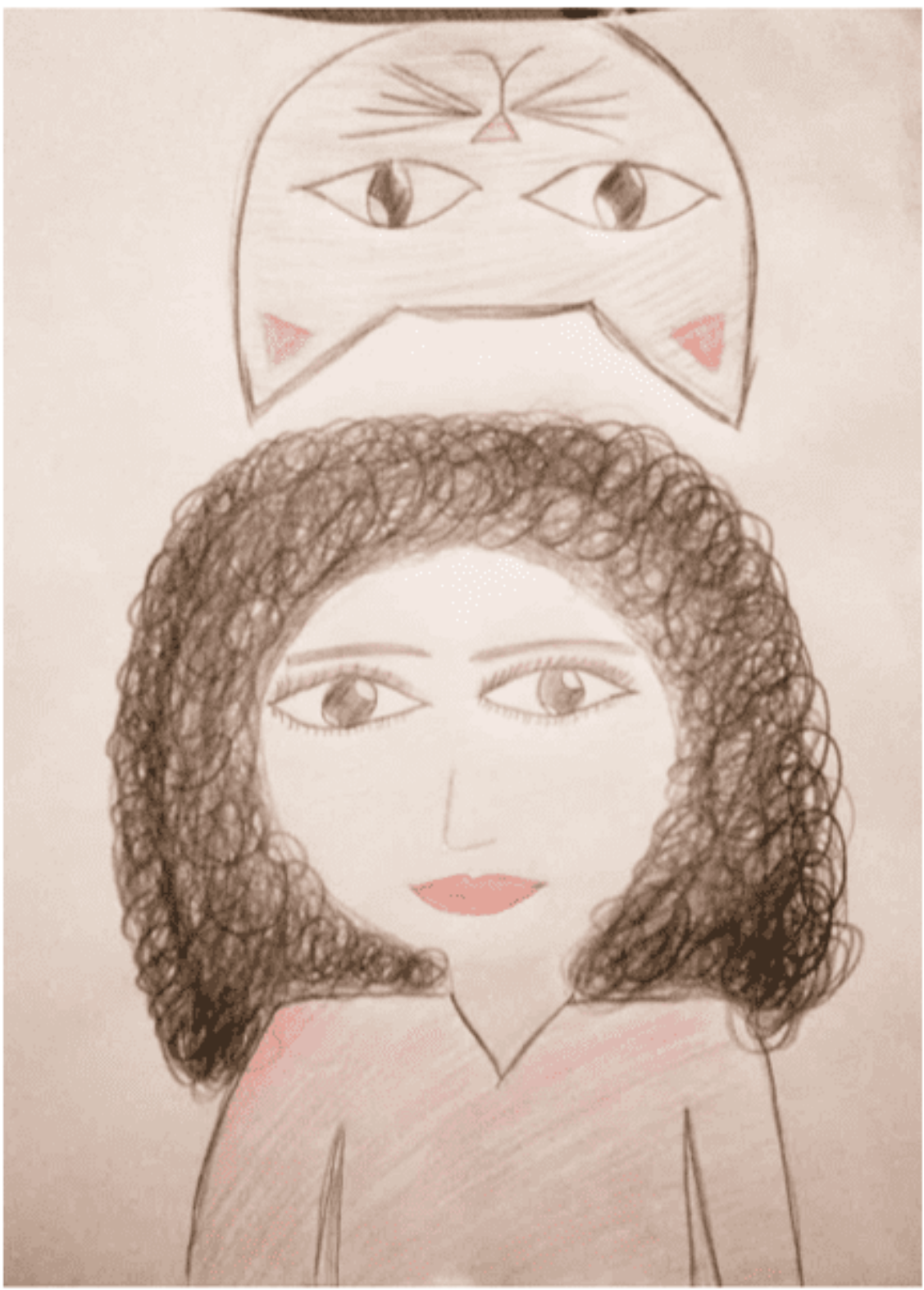

Fonte: arquivo da equipe.

A adolescente optou em começar o desenho com lápis de grafite. Usou muitas vezes a borracha, assim como, utilizou-se de poucas cores de lápis de cor. Quando perguntado o que ela havia feito, respondeu que desenhou a estudante de Psicologia

RC: 105382

Disponível em: https://www.nucleodoconhecimento.com.br/psicologia/perspectiva-piagetiana 
que Ihe pediu para fazer o desenho e seu gato. Quando questionada do porquê de desenhar a acadêmica, informou que não sabia o que desenhar, por isso tomou a iniciativa de reproduzi-la.

Um detalhe interessante, é que a voluntária disse que representou a estudante mais velha, projetando para muito mais 30 anos de idade (a aluna de Psicologia tem atualmente 20 anos, e conforme a explicação da voluntária, estaria cerca de 19 anos à frente). Ao ser inquirida do porquê disso, apenas respondeu, "Porque sim". Lowenfeld e Brittain (1977) veem isso como simbologia e mostrando a capacidade de ter pensamentos abstratos como é esperado na fase de operações formais levantadas nos estudos de Piaget (1994; 1999).

Analisando mais detalhadamente a ilustração a partir dos traços e materiais, vê-se que a criança tenta reproduzir o real e o metafísico como linguagem abstrata. A criança voluntária estaria dentro da quarta etapa de evolução do grafismo de Luquet (1969), o realismo visual. Assim, ela representa em conformidade com sua idade, desenhos de âmbito mais adulto, com uma perspectiva mais realista e privilegiando a estética.

Tanto a representação humana, quanto a animal apresentam olhos, boca e nariz, assim como detalhes como sobrancelhas, cílios, bigodes do gato e outros pequenos detalhes. O semblante abstrato de ambos apresenta vivacidade e calma, tendo ainda a peculiaridade do reflexo de luz na íris, dando assim, uma característica de como se estivessem encarando o observador, e vivos.

Ela escolheu o uso do papel verticalizado, e que conforme Carrano e Requião (2013), é indicador fálico, possivelmente no caso de alguém em crescimento (como a adolescente), o que estaria em conformidade com um entendimento de tomada de seus próprios caminhos e decisões; de quem acha que está tendo ou tem um certo

RC: 105382

Disponível em: https://www.nucleodoconhecimento.com.br/psicologia/perspectiva-piagetiana 
poder. Novamente, é bom ressaltar que Meredieu (2000) discorda dessa análise psicológica a partir do posicionamento de papel.

A voluntária escolheu usar para a construção do desenho, lápis grafite e lápis de cor, tendo ainda o apoio da borracha. Esse último, usou constantemente (conforme já relatado), refazendo várias vezes os traços. A borracha pode ser vista também como um elemento de tentativa de reestruturação de caminhos, de ponderações diante de escolhas. Quanto menor a criança, menos ocorre o uso da borracha, e justamente por ela não necessitar fazer tantas estruturas de pensamento, como apoia Piaget (1994; 1999). Isso porque, ela estaria organizando novas regras, valores e a afirmação de vontade com a regularização e hierarquização moral.

Piaget $(1994 ; 1999)$ nomeou de Pseudo-Naturalismo os desenhos de crianças dos onze anos em diante, onde ela encontra-se na fase das operações abstratas. Para o autor, é o fim da arte como uma atividade espontânea. Há uma maior conscientização no uso de cor, podendo ser objetiva ou subjetiva.

No desenho, o uso do lápis de grafite e recoberto com lápis de cor escuro, fazem uma demarcação de espaço e limites bem definidos e isentos de dúvidas. É quase um reforço de que isso existe. Além disso, como Carrano e Requião (2013) explicaram, esses dois materiais são escolhidos por indivíduos que tendem a se expressar e organizar melhor seus sentimentos e vida, pois ele funciona como base de um esboço para construção de algo mais concreto. No caso da voluntária, essa tentativa de construção foi tão intensa, que ela projetou a estudante pesquisadora num futuro de quase vinte anos adiante.

O esforço em firmar as linhas de contorno, demonstra que a voluntária segue e/ou gosta de impor regras. Ela estabelece limites que não gostaria que fossem ultrapassados. Uma outra curiosidade sobre esses traços de discriminação do desenho, é que eles seguem até o limite do papel, configurando tentativa de fuga ou

RC: 105382

Disponível em: https://www.nucleodoconhecimento.com.br/psicologia/perspectiva-piagetiana 
expansão. Talvez isso se dê pela própria fase de desenvolvimento da voluntária (adolescência), que conforme Piaget (1994; 1999), seu pensamento está em forte ampliação e construindo novas reflexões e teorias além do seio familiar. Ademais, isto é reforçado na pintura dentro do próprio desenho utilizando o lápis de cor. Os espaços são preenchidos inclinados de baixo para cima, tombando para a direita, o que indica que o sujeito possivelmente seja destro. Esse preenchimento foi feito em riscos inteiros, ou pouco espaçados, mas se mantêm dentro dos limites dos traços de contorno (o que em termos normais, geralmente são ultrapassados, mesmo de forma mínima, por alguém não tão rígido e controlador).

Como levantado pelos três teóricos principais para análise deste artigo (e até reforçado por Meredieu, 2000), é possível observar no desenho da criança de 15 anos essa noção de realismo. A figura que ela escolheu desenhar foi a própria pesquisadora acadêmica de Psicologia, que estava em sua frente. A concentração, o uso da borracha e a atenção aos detalhes, mostra a preocupação em encaixar-se no mundo real/adulto.

A voluntária encontra-se na última fase do desenho infantil que Luquet (1969) apresentou em seus estudos (o Realismo Visual), em que a criança imita o que o adulto desenha e começa a se importar mais com a estética. Novamente, a análise embasada também nos materiais utilizados pela voluntária não pode ser mais aprofundada, já que houve limitação de livre escolha de material. Contudo, da união do desenho com o material, e mais os conhecimentos fundamentados nas fases de desenvolvimento de Piaget (1994; 1999), a equipe conseguiu identificar esses pontos explanados sobre o desenho apresentado pela criança voluntária 2.

\subsection{CRIANÇA VOLUNTÁRIA 3 (MM):}

Idade: 02 anos / Escolaridade: Não frequenta escola / Materiais utilizados: Lápis de cor e papel.

RC: 105382

Disponível em: https://www.nucleodoconhecimento.com.br/psicologia/perspectiva-piagetiana 
Figura

$3 \quad-\quad$ Desenho

de

MM:

2

anos

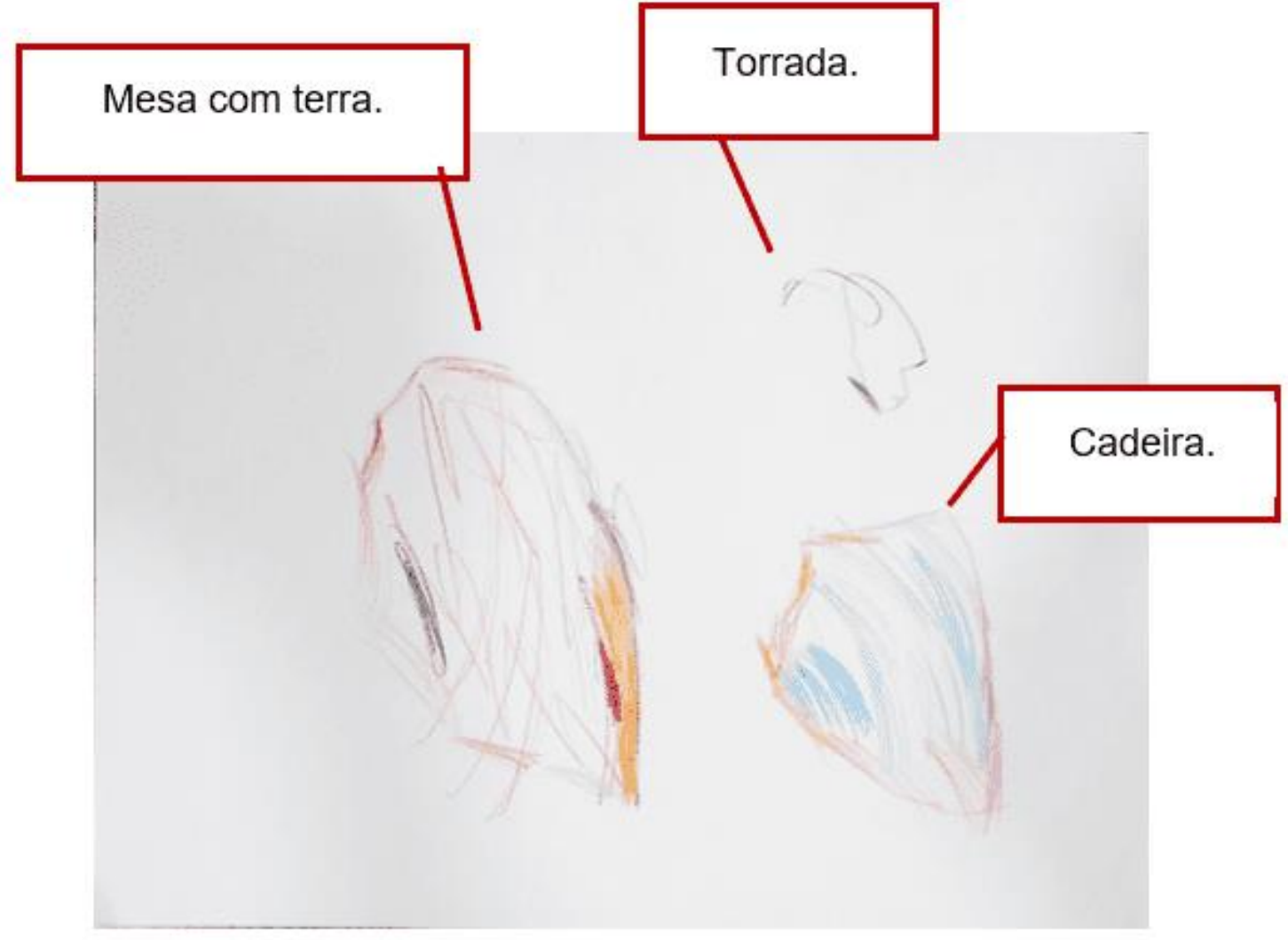

Fonte: arquivo da equipe.

A criança mostrou-se muito encantada com os lápis de cor; ficou observando as cores por um bom tempo, até começar a pensar em que desenho ela faria. Não quis usar o lápis de grafite preto, pois disse que queria que ficasse bem colorido, e conversou muito ao longo da atividade sobre assuntos aleatórios. Sua escolha foi pela horizontalidade da folha e os desenhos ficaram dentro da área do papel, ficando um pouco mais centralizados. Ao fim, ela explicou que o desenho se tratava de uma mesa com terra, uma cadeira e uma torrada.

Esse indivíduo estaria dentro do quarto estágio (inteligência intuitiva, sentimentos interindividuais espontâneos e relações sociais de submissão ao adulto), identificado

RC: 105382

Disponível em: https://www.nucleodoconhecimento.com.br/psicologia/perspectiva-piagetiana 
por Piaget (1994; 1999) como estágio da primeira infância (2 aos 7 anos). Conforme a narrativa do autor e análise do desenho, a criança atendeu as expectativas de alguém muito falante, com a construção de muitas narrativas e extremamente sociável. Ademais, esse indivíduo de dois anos apresenta-se dentro do primeiro estágio do realismo fortuito de Luquet (1969), caracterizado pelo fim do período de rabisco (a garatuja) e dando início a ligação entre seus traços e as figuras, e, nomeando seus desenhos.

\subsection{CRIANÇA VOLUNTÁRIA 4 (ND):}

Idade: 09 anos / Escolaridade: 4ํㅜ ano do ensino fundamental / Materiais utilizados: Lápis de cor (quatro cores) e papel.

Figura 4 - Desenho de ND: 9 anos

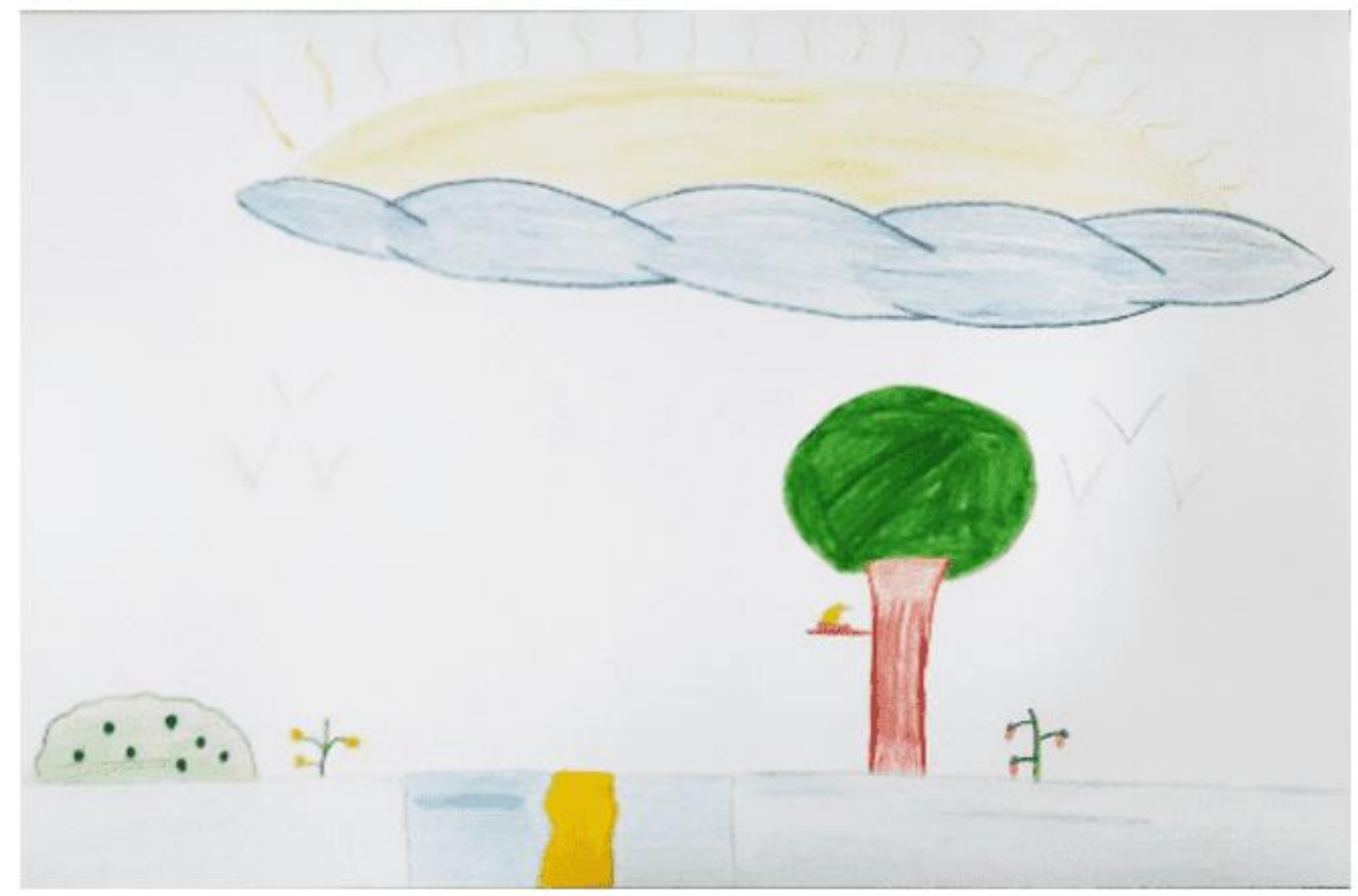

Fonte: arquivo da equipe.

RC: 105382

Disponível em: https://www.nucleodoconhecimento.com.br/psicologia/perspectiva-piagetiana 
A menor (criança voluntária 1) teve bastante dificuldade em saber o que seria desenhado, usou várias cores, e após começar o desenho, conseguiu fazer bem rápido e decidida, sem usar a borracha, nem pedir outra folha. Não conversou nem um pouco durante a realização da atividade, e quando terminou, disse que se tratava de um jardim que "veio em sua cabeça".

A criança voluntária 1 (8 anos), a voluntária 4 (9 anos) apresentaram algumas similaridades, a começar pelo tempo pensando no que fazer. A liberdade de produzir o que queria, mas, com o entendimento que deveria planejar, apresentou-se em ambos os indivíduos. Se o indivíduo 1 buscou a segurança na caneta hidrográfica, o sujeito 4 ficou concentrado no que fazia. Ambos também se negaram a usar borracha para correções. As escolhas pela horizontalidade da folha também foram idênticas, e os desenhos se expandiram para fora da área do papel.

A terceira similaridade surgiu no contexto geral de escolha de temática. Enquanto o voluntário 1 escolheu a representação de sua casa, o voluntário 4 decidiu representar um jardim com muitos detalhes. Contudo, a criança 4 fez a escolha pelo lápis de cor, tentando ainda usar todos os espaços da folha inclusive vazando o desenho como se tivesse continuidade externa. Os traços eram seguros e firmes nos elementos principais, e a coloração foi bem demarcada dentro dos limites dos traços de contorno.

Uma curiosidade: ela usou muitas formas curvas e ao centro existe um pequeno rio, assim como a árvore apresenta um galho protegido abaixo da copa, que também possui um ninho de passarinho (com a mãe no ninho). Isso seria análogo à ponderação trazida por Meredieu (2000) de que as formas esféricas e representação de água (rio ou lago) trariam a lembrança inconsciente do útero, e, portanto, trazendoIhes tranquilidade e segurança. Ademais, o cenário apresenta o esforço da perspectiva, tentando criar uma noção de profundidade e distância, mas as relações topográficas ainda estão em tentativa de construção. A planificação e o rebatimento se fazem presentes.

RC: 105382

Disponível em: https://www.nucleodoconhecimento.com.br/psicologia/perspectiva-piagetiana 
Portanto, assim como ocorreu com o voluntário 1, o voluntário 4 encaixa-se na quinta fase estrutural de desenvolvimento de Piaget (1994; 1999), construindo novas relações sociais para a formatação e construção das interações cognitivas e de sociabilização. E por fim, assim como o indivíduo 1, a criança voluntária 4 também estaria dentro da terceira etapa de evolução do grafismo de Luquet (1969): o realismo intelectual.

\section{CONSIDERAÇÕES FINAIS}

É importante a linguagem expressada pelo desenho, já que as crianças têm mais dificuldade de expor em palavras o que passam, sentem ou querem dizer.

No decorrer e finalização do estudo avaliativo foi possível responder positivamente tanto o problema norteador - é possível se detectar diferenças no desenvolvimento psíquico de crianças e apontar fatores comportamentais e emocionais por meio de desenhos? -, quanto à hipótese preliminar. Sendo possível detectar diferenças no desenvolvimento psíquico das crianças abordadas e apontar fatores comportamentais e emocionais por meio de seus desenhos. A identificação e avaliação das fases de desenvolvimento das crianças por meio de desenhos foram tangíveis, possibilitando detectar em cada pequeno voluntário atual o cruzamento com a teorização de Piaget de quase um século. Apesar das crianças contemporâneas apresentarem acelerações de desenvolvimento, os recortes temporais e comportamentos são análogos com os menores observados por Piaget.

As diferenças entre as fases das crianças e de que elas seriam óbvias de identificação a partir do conhecimento dos estudos teóricos visto aqui neste artigo, foram respeitadas. Sim; esses fatores são óbvios diante da compreensão dos conceitos, e não apenas pela própria defasagem de, por exemplo, olhar-se um indivíduo de 2 anos e compará-lo com alguém de 9 anos e de 15 anos.

RC: 105382

Disponível em: https://www.nucleodoconhecimento.com.br/psicologia/perspectiva-piagetiana 
As sutilezas do desenvolvimento psíquico e daquilo que não está aparente ao olhar e julgamento, surge nos traços não formatados pela fala. Ficou evidente que é cabível identificar as fases que Piaget $(1994 ; 1999)$ através do desenho e relacionar ao momento em que a criança se encontra. Reforça-se, portanto, a importância que os desenhos possuem como um dos métodos usados pela Psicologia, para entender o que se passa no corpo e na mente da criança (e até dos indivíduos de uma forma geral, independentemente de sua idade). Portanto, é possível entender a personalidade e angústias de uma pessoa pelo grafismo.

Foi possível compreender que os materiais utilizados na elaboração dos desenhos podem efetivamente corroborar com a leitura psicológica, e auxiliar no cruzamento de teorias como de Piaget, Luquet e outros autores, para uma leitura amplificada de avaliação da adequação de fase etária e mental do indivíduo, além da análise de seus conteúdos psíquicos e comportamentais.

A equipe descobriu que a identificação das diferenças das fases infantis torna-se possível ao dar-se nomes e significados às grandes-pequenas ações que as crianças realizam - e que no dia a dia, tornam-se comuns e sem significados. Nesse processo, os materiais também já elucidam por eles mesmos as estruturas psicológicas dos sujeitos. Papel, grafites, pastéis, tintas, colas e outros: todos possuem funções que vão muito além de mera reprodução gráfica ou artística. Eles são as ferramentas que precipitam na totalidade algo mais profundo da consciência do sujeito, e completam lacunas que, dependendo da idade do indivíduo, podem sofrer a manipulação de estado emocional.

É notável, depois do entendimento das obras aqui citadas, a influência do meio não apenas no desenvolvimento infantil, mas também em sua criatividade e originalidade. Além disso, percebe-se como as condições - os materiais no caso do grafismo infantil, e o ambiente no caso do desenvolvimento psicomotor da criança -, são imprescindíveis para a criança atingir (ou não) seu potencial.

RC: 105382

Disponível em: https://www.nucleodoconhecimento.com.br/psicologia/perspectiva-piagetiana 
Como os autores pesquisados mencionaram, o adolescente está mais concentrado nos detalhes, na reprodução das obras adultas, em não errar. Além disso, está ligado às ideias abstratas (operações formais). Esse cenário de desenvolvimento do adolescente, fica claro ao analisarmos o desenho da voluntária de quinze anos, pois ela usou com frequência a borracha ao tentar chegar em uma "perfeição" estética e apagando seus "erros". Ademais, o desenho foi ao mesmo tempo real e metafísico: a voluntária desenhou a estudante de Psicologia que fazia a coleta de dados (além de projetá-la no futuro, 19 anos à frente), e desenhou seu gato com o máximo de detalhes possíveis.

Todas as crianças observadas e analisadas apresentaram suas fases de desenvolvimento análogas aos estudos de Piaget (1994; 1999) e Luquet (1969), os dois principais pesquisadores fundamentais deste trabalho, mas, sem esquecer também do apoio de Lowenfeld e Brittain (1977) e Meredieu (2000), assim como, dos outros teóricos utilizados como suporte. Todas as teorizações foram fidedignas aos dados coletados, observados e analisados das crianças voluntárias.

Em um contexto geral, o conhecimento das fases do desenvolvimento humano piagetiano, com o significado psicológico através dos desenhos, e da linguagem psíquica nos próprios materiais utilizados, formam uma poderosa ferramenta para profissionais bem treinados nessas vertentes, realizarem uma leitura precisa a respeito não somente das demandas do indivíduo, mas igualmente por quais percursos de condução conseguirão tratá-lo.

\section{REFERÊNCIAS}

BUCK, John N. H-T-P: casa-árvore-pessoa - técnica projetiva de desenho: manual e guia de interpretação. São Paulo: Vetor, 2003.

CARRANO, Eveline; REQUIÃO, Maria Helena. Materiais de arte: sua linguagem subjetiva para o trabalho terapêutico e pedagógico. Rio de Janeiro: Wak Editora, 2013. RC: 105382

Disponível em: https://www.nucleodoconhecimento.com.br/psicologia/perspectiva-piagetiana 
FARTHING, Stephen. Tudo sobre arte. Tradução Paulo Polzonoff Jr. et. al. Rio de Janeiro: Sextante, 2011.

FREUD, Sigmund. Edição Standart Brasileira das Obras Psicológicas Completas de Sigmund Freud. Rio de Janeiro: Imago, 1972.

KLEIN, Melanie. Obras Completas. Rio de Janeiro: Imago Editora, 1991-1997.

LOWENFELD, Viktor; BRITTAIN, W. Lambert. Desenvolvimento da Capacidade Criadora. São Paulo: Mestre Jou, 1977.

LUQUET, Georges-Henri. O desenho infantil. Porto: Editora do Minho, 1969.

MEREDIEU, Florence de. O desenho infantil. Tradução Álvaro Lorencini e Sandra M. Nitrini. São Paulo: Cultrix, 2000.

PIAGET, Jean. O Juízo Moral na Criança. 3. ed. São Paulo: Summus, 1994.

. Seis estudos de Psicologia. Tradução de Maria Alice Magalhães D’Amorim e Paulo Sérgio Lima da Silva. 24. ed. Rio de Janeiro: Forense Universitária, 1999.

OCAMPO, Maria Luisa Siquier de; et al. O processo psicodiagnóstico e as técnicas projetivas. 11. ed. São Paulo: Martins Fontes, 2005.

RETONDO, Maria Florentina N. Godinho. Manual prático de avaliação do HTP (casa-árvore-pessoa) e família. São Paulo: Casa do Psicólogo, 2000.

Enviado: Julho, 2021.

Aprovado: Janeiro, 2022.

RC: 105382

Disponível em: https://www.nucleodoconhecimento.com.br/psicologia/perspectiva-piagetiana 